\title{
Morphological, mineralogical and geochemical features of topomorphic vertisols used for sorghum production in North Cameroon
}

\section{Simon Djakba Basga ${ }^{a, *}$, Jean Pierre Temga b, Désiré Tsozué c, Nicodème Danbé $d$, Jean Pierre Nguetnkam e}

\author{
a Institute of Agricultural Research for Development (IRAD), Yagoua, Cameroon \\ b Department of Earth Sciences, Faculty of Science, University of Yaoundé, Yaoundé, Cameroon \\ c Department of Earth Sciences, Faculty of Science, University of Maroua. Maroua, Cameroon \\ d Institute of Agricultural Research for Development (IRAD), Maroua, Cameroon \\ e Department of Earth Sciences, Faculty of Science, University of Ngaoundéré, Ngaoundéré, Cameroon
}

\section{Article Info}

Received : 13.02 .2018

Accepted : 27.08.2018

\begin{abstract}
In the present study, two topomorphic vertisols profiles used for sorghum production were described and characterized. After macroscopic characterization, physicochemical, mineralogical and geochemical analyses were made. Physicochemical analyses were made by standard methods while mineralogy was determined on clay fraction $(<2 \mu \mathrm{m})$ by X-ray diffraction coupled to Fourier transform infrared spectroscopy. Geochemical analysis was determined on $180 \mu \mathrm{m}$ fraction by inductively coupled plasma- Atomic Emission Spectroscopy (ICP-AES) and mass spectrometry (ICP-MS). Results revealed that studied vertisols were average deep, less differentiated with desiccations cracks and gilgai micro relief. The angular blocky structure and clayey texture were observed. They were alkaline $\left(7.3 \leq \mathrm{pH}_{\text {water }} \leq 8.4\right)$ and recorded a low to moderate organic matter and nitrogen contents. Cation exchange capacity was high reaching 52.24 meq $100 \mathrm{~g}^{-1}$ and exchangeable cations were moderates with $\mathrm{Ca}^{2+}\left(3.69-29.6\right.$ meq $\left.100 \mathrm{~g}^{-1}\right)$ the most represented cation. Vertisols were made of smectites associated to kaolinite and a lesser content of quartz. Illites and calcite were also identified in some horizons. On the geochemical point of view, Si02 (55.87- 83.64\%), $\mathrm{Al}_{2} \mathrm{O}_{3}$ (6.08-20.25\%), $\mathrm{Fe}_{2} \mathrm{O}_{3}$ (2.09-6.39\%) and $\mathrm{K}_{2} \mathrm{O}$ (1.43-2.24 \%) were the dominant oxides. Traces elements were represented essentially by Ba (518-1202 mg $\left.\mathrm{kg}^{-1}\right), \mathrm{Zr}\left(334-685 \mathrm{mg} \mathrm{kg}^{-1}\right)$ and $\mathrm{Sr}$ (71-190 $\left.\mathrm{mg} \mathrm{kg}^{-1}\right)$. The overall features are suitable to dry season sorghum production. The amount of smectites seemed to be an important factor affecting their water holding capacity on which dry season sorghum production depends. Improved cropping systems have to be developed to sustain productivity in vertisols with low smectites and where annual rainfall is lesser.
\end{abstract}

Keywords: Topomorphic vertisols, clay, smectites, dry season sorghum, North Cameroon. (c) 2018 Federation of Eurasian Soil Science Societies. All rights reserved

\section{Introduction}

Vertisols are defined as clayey dark soils typical of tropical area which enjoy contrasting climate alternating wet and dry seasons. They also occurred in humid and temperate regions (Dudal, 1965; Coulombe et al., 1996). Morphology is the major feature used to distinguish them from the other soils type (Dudal, 1965; Wilding, 2004; Tamfuh et al., 2011; Temga et al., 2015; Rahim et al., 2015). The gilgai micro relief, the desiccation cracks and slickensides were dominant features common to vertisols over the world (Dudal, 1965; Dudal and Eswaran, 1988; Wilding, 2004; Kovda and Wilding, 2004; Tamfuh et al., 2011; Rahim et al., 2015). These features are due to their high clay content and the predominance of expanding clay minerals

\footnotetext{
${ }^{*}$ Corresponding author.

Institute of Agricultural Research for Development (IRAD), P.O. Box 12 Yagoua, Cameroon

Tel.: +23799608697
}

e-ISSN: $2147-4249$

E-mail address: simonbajak@yahoo.fr DOI: $10.18393 /$ ejss.460841 
which controls the swelling and shrinking pattern (Dudal and Eswaran, 1988; Tamfuh et al., 2011; Adjia et al., 2013; Rahim et al., 2015).

In Cameroon, vertisols were found in sudano sahelian zone globally between $8^{\circ}$ and $13^{\circ} \mathrm{N}$ and between $12^{\circ}$ and $16^{\circ} \mathrm{E}$ (Brabant and Gavaud, 1985; Raunet, 2003; Nguetnkam, 2004; Tamfuh et al., 2011; Temga et al., 2015). These soils which were very widespread, covering about 1200000 ha were used for brick production and for agricultural purposes (Brabant and Gavaud, 1985; Coulombe et al., 1996; Raunet, 2003; Tamfuh et al., 2011; Temga et al., 2015). They were considered as very fertile with respect to their physicochemical properties. They were used to grown annual crops such as sorghum, rice and cotton (Coulombe et al., 1996; Ambassa-Kiki et al., 1996; Ben Hassine, 2006; Tamfuh et al., 2011). An important part of vertisols was subjected to dry season sorghum production (Mathieu, 2005). But, due to their heavy texture, they were difficult to manage (Coulombe et al., 1996; Ambassa-Kiki et al., 1996; Azinwi et al., 2011). The management problems were related to their extreme stickiness when wet and their hardness when dry (Tamfuh, 2012). The seasonal flooding pattern constitutes another important constraint to their cropping in rainy season because it limits the growing period. According to Tamfuh (2012), the vertisols physical properties and moisture regime constitute serious management constraints to their use in agriculture. For instance, large areas of vertisols were left on fallow or used for grazing and as earth crude materials in house building (Ambassa-Kiki et al., 1996; Temga et al., 2015).

Two major types of vertisols were observed in North Cameroon in regard to their parent materials (Brabant and Gavaud, 1985; Raunet, 2003; Nguetnkam, 2004; Tamfuh et al., 2011; Temga et al., 2015). The lithomorphic vertisols were developed on a wide range of rocks mainly igneous and metamorphic (Nguetnkam, 2004; Tamfuh et al., 2011). The topomorphic vertisols were more widespread than lithomorphic. They were formed on alluvial and colluvial materials generally in low landscape positions notably in rivers valleys and floodplains poorly or imperfectly drained, suitable to bases accumulation and bisiallitisation process (Blanchart et al., 2000; Raunet, 2003; Tamfuh et al., 2011; Temga et al., 2015).

Soils distribution in Northern Cameroon is governed by climate, parent material and the topography (Brabant and Gavaud, 1985; Raunet, 2003; Tamfuh et al., 2011). Thus, the same soils type can differ from one area to another. This is the case of soils developed on alluvial material specifically topomorphic vertisols. The dry season sorghum cultivation was concerned only vertisols. However, due to demographic pressure observed these last years, it production was extended to others clayey soils units (Coulombe et al., 1996; Mathieu et al., 2002, Mathieu, 2005). Nowadays, topomorphic vertisols used for sorghum production were not well known. The aim of this study is to describe these topomorphic vertisols on the morphological, mineralogical and geochemical point of view. It also, focuses on the influence of vertisols features on dry season sorghum productivity.

\section{Material and Methods}

\section{Study site}

The study was investigated in the sudano-sahelian zone of Cameroon especially in Mayo Danay division. Two localities were considered mainly Bougaye and Velé (Figure 1) for their contribution to sorghum production. This part of North Cameroon experiences the tropical climate type with a pronounced dry season which was about height months extending from October to May. The mean annual rainfall and the mean annual air temperature in the area are $800 \mathrm{~mm}$ and $29^{\circ} \mathrm{C}$ respectively. On the geomorphological point of view, the study site is dominated by plains with altitude less than $400 \mathrm{~m}$ above the sea level and a few gentle dune slopes. An important part of these plain called yaere is sometimes flooded during the wet season. The natural vegetation is dry savannah with rare tree species notably in yaere where grassland dominated. The only tree species observed were Balanites aegyptiaca, Ziziphus mauritiana, Faidherbia albida, Combretum sp and Bombax costatum. The study area was covered mainly by vertisols and arenosols (WRB, 2014). Vertisols were observed in low altitude notably in alluvial depressions while the relative high altitudes were globally occupied by arenosols (Brabant and Gavaud, 1985; Raunet, 2003).

\section{Methods}

Field work consisted of direct observations, description of environmental settings and soil survey in order to choose the position of pits. One pit was dug in each site and described in detail according to the standard procedure. The main search characters were colour, thickness of horizons, coarse elements, texture, structure, porosity, consistency and boundaries between horizons. The Munsell Soil Color Chart (2014) was used for color appreciation. Soils samples were thereafter collected from any horizon and packaged in plastic bags, labeled and sent to the laboratory for soil analyses. 


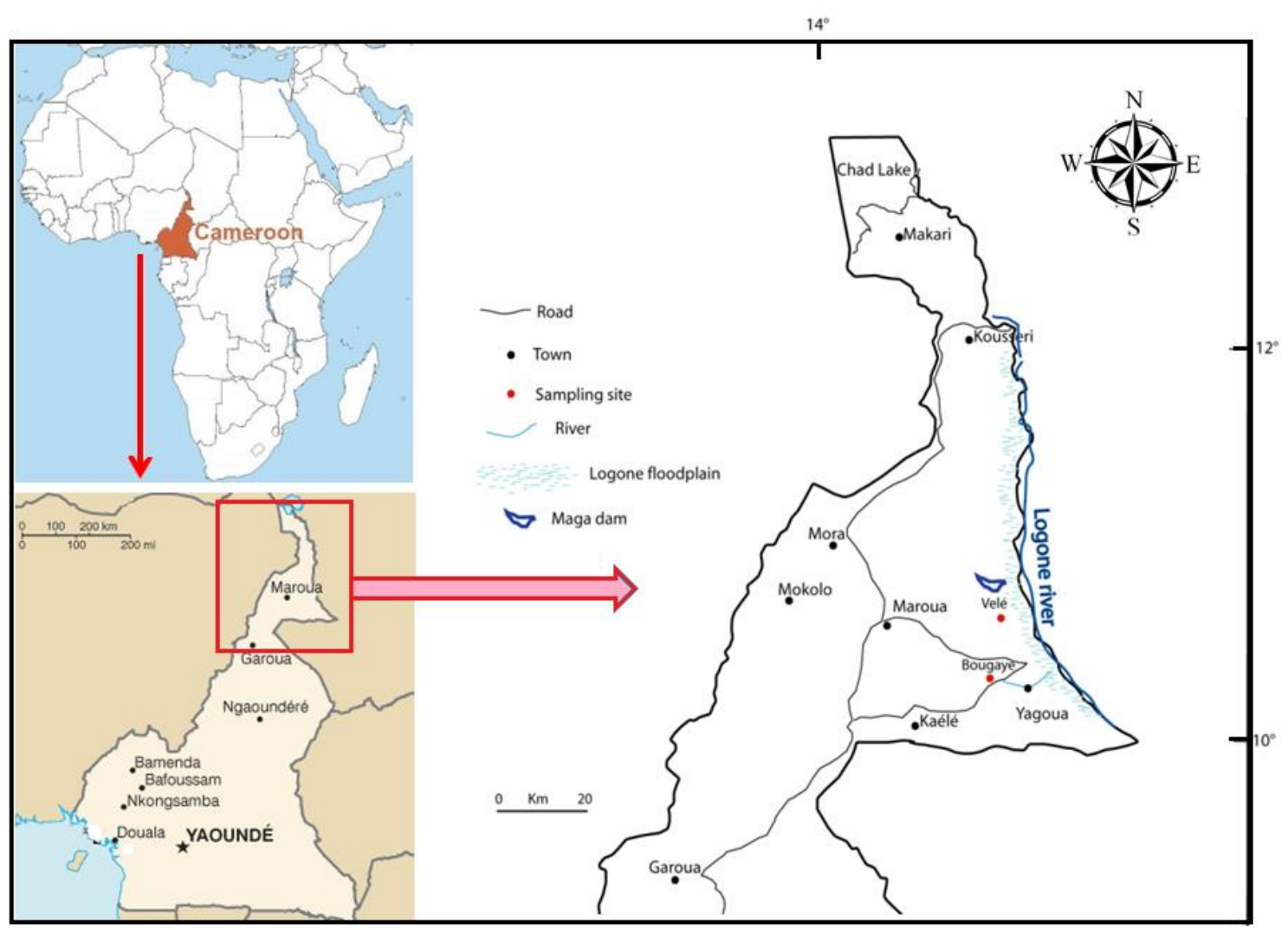

Figure 1. Location of the sampled sites

In the laboratory, bulk soil samples were air-dried at room temperature and then sieved $(2 \mathrm{~mm})$ to discard coarse fragments. The pipette method was used for particle size distribution analysis after dispersion with sodium hexametaphosphate $\left(\mathrm{NaPO}_{3}\right)_{6}$ and organic matter destruction by hydrogen peroxide $\left(\mathrm{H}_{2} \mathrm{O}_{2}\right)$. Soil $\mathrm{pH}$ was measured in water and $\mathrm{KCl}$ via $\mathrm{pH}$ meter equipped with a glass electrode in 1:2.5 soil-water suspensions. The soil organic carbon (OC) was determined by the wet oxidation method (Walkley and Black, 1934). The content in organic matter was calculated by multiplying the organic carbon values by the factor 1.72. The total nitrogen was measured by the Kjeldahl method. Available phosphorus was determined according to Bray II procedure. Exchangeable cations were dosed by ammonium acetate extraction method at pH 7 and Cation Exchange Capacity (CEC) was determined using the sodium saturation method.

Soil mineralogy was determined on oriented clay samples by X-ray diffraction (XRD) and Fourier transform infrared spectroscopy (FTIR) at the Institute of soil sciences of Leibniz University in Germany. The clay fraction $(<2 \mu \mathrm{m})$ was separated first by dispersing in deionized water and sedimentation according to Stoke's law. The resulting clay suspension was freeze-dried. The D8 Bruker diffractometer with CoK 1 radiation $(\lambda=1,789 \AA)$ was used for XRD data recording. IR spectra were recorded using Fourier transform spectrometer Bruker IFS 55 type.

The inductively coupled plasma source (ICP) was performed on $180 \mu \mathrm{m}$ fraction for geochemical analyses. The major elements were determined by atomic emission spectroscopy (ICP-AES) while trace elements by mass spectrometry (ICP-MS) after fusion in LiBO2 and dissolution in nitric acid $\left(\mathrm{HNO}_{3}\right)$. The detection limit was $1 \%$ for major elements. For trace elements, it was $5 \mathrm{mg} \mathrm{kg}^{-1}(\mathrm{Ba}, \mathrm{Zr}, \mathrm{Nb}), 20 \mathrm{mg} \mathrm{kg}^{-1}$ (Ni) and $4 \mathrm{mg} \mathrm{kg}^{-1}$ (Y, Sc, Sr).

\section{Results}

\section{Morphology, texture and chemical characteristics of soils}

In velé, vertisol profile $\left(10^{\circ} 29^{\prime} 96^{\prime \prime} \mathrm{N} ; 15^{\circ} 10^{\prime} 92^{\prime \prime} \mathrm{E}\right.$; $321 \mathrm{~m}$ above sea level) presented six different horizons with some desiccation cracks at surface. From the top to the bottom, following horizons were observed:

0 -35 cm: $A_{1}$ horizon; gray (2.5Y 5/1); polyhedral macrostructure; sandy clay; compact; gradual boundary with the underlying horizon; 
$35-140 \mathrm{~cm}: \mathrm{B}_{1 \mathrm{t}}$ horizon; dark gray (2.5Y 6/1); angular blocky to sub angular structure; heavy clayey; too compact; presence of quartz fragments; gradual boundary with the underlying horizon;

140 - $240 \mathrm{~cm}: \mathrm{B}_{21 \mathrm{tca}}$ horizon; gray (2.5Y 5/1); angular blocky; clayey; calcareous nodules; presence of slickensides; gradual boundary with the underlying horizon;

240 - $345 \mathrm{~cm}$ : $\mathrm{B}_{22 \mathrm{Ca}}$ horizon; dark gray (2.5Y 6/1); angular blocky; clayey; calcareous nodules; yellowish spots (10YR 7/6); gradual boundary with the underlying horizon;

345 - $380 \mathrm{~cm}$ : $\mathrm{B}_{23 \mathrm{Cag}}$ horizon; gray (2.5Y 5/1); angular blocky; clayey; calcareous nodules; too compact; few (5\%) yellow spots (5YR 6/6); plastic; gradual boundary with the underlying horizon;

380 - 405 cm: B 3 Gorizon; light gray (2.5Y 7/2); angular blocky; clayey; brownish spots (7.5YR 5/6); humid; plastic.

Pit from Bougaye $\left(10^{\circ} 15^{\prime} 92^{\prime \prime} \mathrm{N}\right.$; $15^{\circ} 06^{\prime} 06^{\prime \prime} \mathrm{E}$; $334 \mathrm{~m}$ above sea level) was opened in the flooded depression where dry season sorghum field were installed. Some desiccations cracks and gilgai micro relief were observed at the surface soil. From the top to the bottom, following horizons were observed:

0 - $16 \mathrm{~cm}$ : $A_{\mathrm{p}}$ horizon, gray (2.5Y 5/1), angular blocky; sandy clay; porous; desiccations cracks; hard and too compact; gradual boundary with the underlying horizon;

$16-35 \mathrm{~cm}$ : $\mathrm{B}_{1 \mathrm{t}}$ horizon, gray (2.5Y 6/1); angular blocky; clayey; compact; gradual boundary with the underlying horizon;

35-100 cm: $B_{21 t c a}$ horizon; brownish gray (2.5Y 6/2); angular blocky; clayey; calcareous nodules (3 to 4 $\mathrm{mm}^{3}$ ) which diminish from the top to the bottom of the horizon; too compact; gradual boundary with the underlying horizon;

100- $190 \mathrm{~cm}$ : $\mathrm{B}_{22 \mathrm{tca}}$ horizon; light gray (2.5Y 7/2); angular blocky; more calcareous nodules; clayey; plastic; gradual boundary with the underlying horizon;

190-270 cm: B 3 horizon; light gray (2.5Y 7/1); sub angular blocky; sandy clay; compact; plastic.

Particle size distribution revealed that studied vertisols were ranged from clayey to sandy clay. Clay content quite decreases from the top to the bottom of the profile (Table 1). In contrast, sand proportion displayed an opposite trend. The organic carbon (OC) and total nitrogen (TN) were globally moderate and uniformly distributed throughout the profiles. Relative higher OM values were observed at the bottom of the profiles (Table 1).

Table 1. Physico-chemicals characteristics of the studied vertisols

\begin{tabular}{|c|c|c|c|c|c|c|c|c|c|c|c|c|c|c|}
\hline \multirow{2}{*}{$\begin{array}{l}\text { Depth }(\mathrm{cm}) \\
\text { Horizon }\end{array}$} & \multicolumn{4}{|c|}{ Particle size distribution (\%) } & \multirow{2}{*}{$\begin{array}{l}\text { OC, } \\
\%\end{array}$} & \multirow{2}{*}{$\begin{array}{l}\text { TN, } \\
\%\end{array}$} & \multicolumn{4}{|c|}{ Cations, meq100g-1 } & \multirow{2}{*}{$\begin{array}{c}\text { CEC, } \\
\text { meq100g-1 }^{-1}\end{array}$} & \multirow{2}{*}{$\begin{array}{c}\text { Av P } \\
\text { mgkg- }^{-1}\end{array}$} & \multicolumn{2}{|c|}{ pH } \\
\hline & Clay & Silt & Sand & Class & & & $\mathrm{Ca}^{2+}$ & $\mathbf{M g}^{2+}$ & $\mathbf{K}^{+}$ & $\mathrm{Na}^{+}$ & & & in $\mathrm{H}_{2} \mathrm{O}$ & in $\mathrm{KCl}$ \\
\hline \multicolumn{15}{|l|}{ Velé profile } \\
\hline$A_{1}(0-35)$ & 38 & 25 & 37 & $\mathrm{C}$ & 2.06 & 1.05 & 5.47 & 1.08 & 0.019 & 0.018 & 22.40 & 38.96 & 7.5 & 6.3 \\
\hline $\mathrm{B}_{1 \mathrm{t}}(35-140)$ & 47 & 30 & 23 & $\mathrm{C}$ & 2.34 & 0.78 & 7.80 & 1.06 & 0.024 & 0.016 & 24.80 & 16.06 & 8 & 6.7 \\
\hline $\mathrm{B}_{21 \mathrm{tCa}}(140-240)$ & 50 & 28 & 22 & $\mathrm{HC}$ & 1.46 & 1.34 & 7.73 & 0.84 & 0.087 & 0.012 & 27.76 & 20.64 & 8.2 & 7 \\
\hline $\mathrm{B}_{22 \mathrm{tCa}}(240-345)$ & 41 & 25 & 34 & $\mathrm{C}$ & 2.62 & 0.49 & 10.22 & 0.93 & 0.101 & 0.021 & 16.00 & 7.23 & 8.1 & 7.1 \\
\hline $\mathrm{B}_{23 \mathrm{tCag}}(345-380)$ & 44 & 26 & 30 & $\mathrm{C}$ & 3.47 & 1.10 & 5.66 & 0.72 & 0.113 & 0.02 & 20.80 & 17.2 & 8.4 & 7.2 \\
\hline $\mathrm{B}_{3 \mathrm{G}}(380-405)$ & 50 & 20 & 30 & $\mathrm{HC}$ & 1.26 & 0.62 & 3.69 & 0.91 & 0.191 & 0.025 & 22.00 & 7.87 & 8.1 & 6.6 \\
\hline \multicolumn{15}{|l|}{ Bougaye profile } \\
\hline$A_{1}(0-16)$ & 26 & 24 & 50 & CSS & 1.07 & 0.58 & 26.1 & 0.5 & 0.040 & 0.012 & 37.84 & 8.26 & 7.3 & 5.6 \\
\hline $\mathrm{B}_{1 \mathrm{tCa}}(16-35)$ & 29 & 22 & 49 & SC & 1.92 & 0.42 & 27.1 & 0.25 & 0.036 & 0.045 & 49.12 & 8.51 & 7.4 & 5.7 \\
\hline $\mathrm{B}_{21 \mathrm{tCa}}(35-100)$ & 32 & 21 & 47 & SC & 0.74 & 0.46 & 29.1 & 1.02 & 0.037 & 0.058 & 50.72 & 8.44 & 7.8 & 6.3 \\
\hline $\mathrm{B}_{22 \mathrm{tCa}}(100-190)$ & 35 & 25 & 40 & $\mathrm{C}$ & 1.60 & 0.50 & 29.6 & 0.69 & 0.036 & 0.007 & 52.24 & 17.55 & 8.2 & 7 \\
\hline $\mathrm{B}_{3 \mathrm{t}}(190-270)$ & 40 & 24 & 36 & $\mathrm{C}$ & 0.50 & 0.81 & 27.6 & 0.56 & 0.036 & 0.024 & 45.36 & 21.68 & 8.4 & 6.7 \\
\hline
\end{tabular}

C=Clay; HC=Heavy Clay; SC=Sandy Clay; CSS=Clayey Sandy Silt; OC=Organic Carbon; TN=Total Nitrogen; Av P= available phosphorus

Vertisols were slightly alkaline to alkaline with $\mathrm{pH} \mathrm{H}_{2} \mathrm{O}$ ranged between 7.3 and 8.4. $\mathrm{Ca}^{2+}(3.6929 .6$ meq $\left.100 \mathrm{~g}^{-1}\right)$ was the most represented cation on the exchangeable sites accounting for more than $80 \%$ of the total of exchangeable bases. The CEC $\left(16.00-52.24\right.$ meq $\left.100 \mathrm{~g}^{-1}\right)$ is high with the highest values in Bougaye vertisols even if their clay content were relatively lesser. In both profiles, CEC increased from the top towards the bottom of the profile. Available phosphorus ranged between 8.26 and $38.96 \mathrm{mg} \mathrm{kg}^{-1}$ indicating low to high available phosphorus contents. The relative higher contents were recorded in Velé in which content decreased from the top to the bottom of the profile. An opposite behavior was observed in Bougaye profile (Table 1). 


\section{Mineralogical and geochemical composition}

The XRD patterns of the vertisols clay fraction showed the presence of smectites, kaolinite and quartz. The high peak intensities at 15.04 $\AA$ and $17.18 \AA$ Andicated relative high amount of smectites (Figure 2). The high peaks at $7.32 \AA$ and $3.57 \AA$ in Velé vertisols compared to those from Bougaye suggests relative higher amount of kaolinite. The sharp character of these peaks compared to those from smectites indicate that kaolinite is well-crystallized than smectites. Also, illites were detected in vertisols from Velé mainly by the peak at $10 \AA$. . Quartz occurs in little amount in Bougaye vertisols (Table 2). The presence of smectites was confirmed in IR spectra by the strong band at $3420 \mathrm{~cm}^{-1}$ which expresses the swelling rate of 2:1 minerals and assigned to $\mathrm{OH}$ - stretching vibration (Figure 2). Calcite not observed in XRD-pattern was identified in FT-IR by the band located at $1429 \mathrm{~cm}^{-1}$ and $875 \mathrm{~cm}^{-1}$ attributed to C-O stretching vibrations (Farmer, 1979; Nzeukou Nzeugang et al., 2013). Feldspars commonly observed in vertisols in North Cameroon (Tamfuh et al., 2011; Temga et al., 2015) were not found. It was observed that vertisols from Bougaye displayed higher amount of 2:1 clays minerals than those from Velé. Further, calcite was not found in Velé profile despite the fact that calcareous nodules were observed.

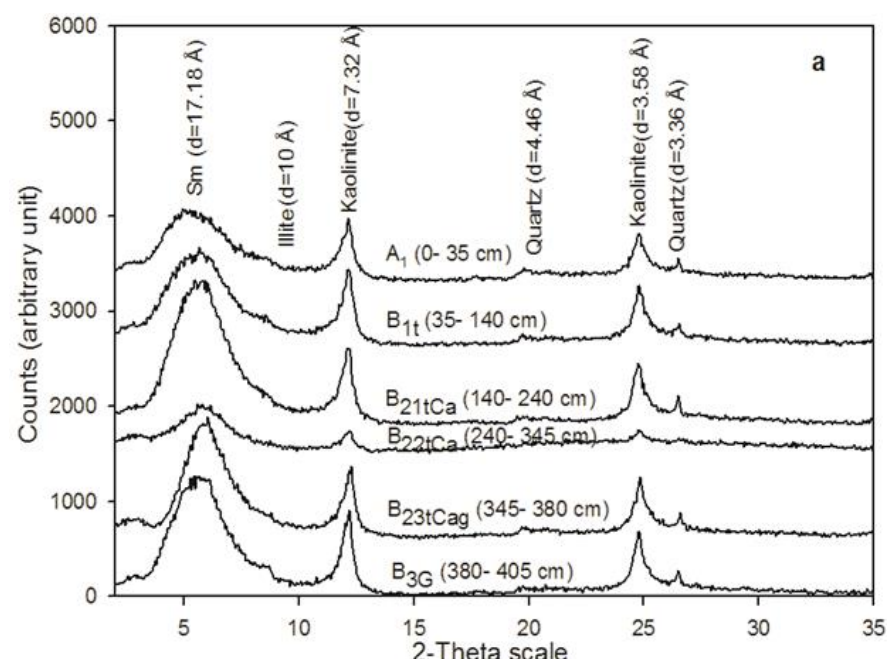

(a)

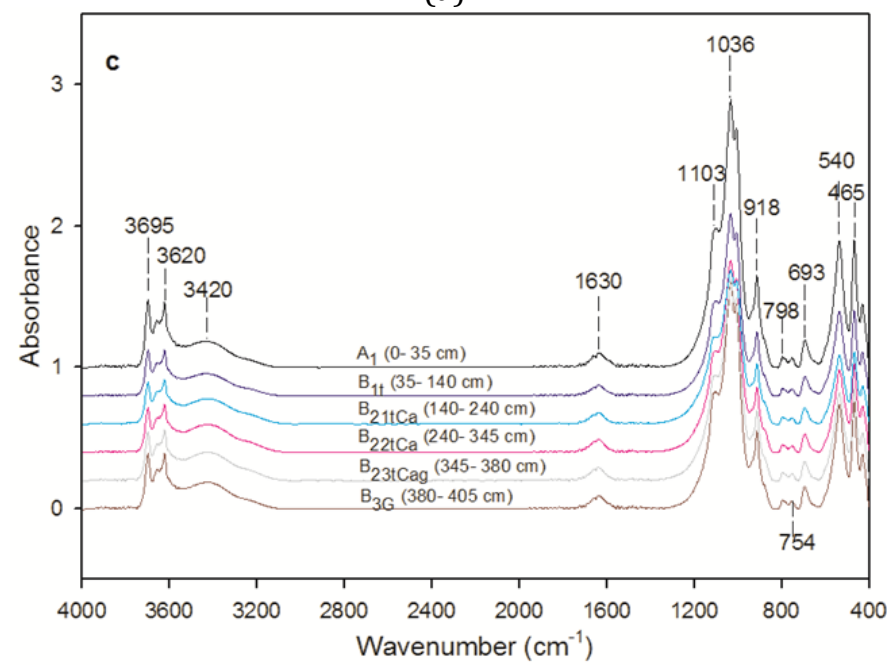

(c)

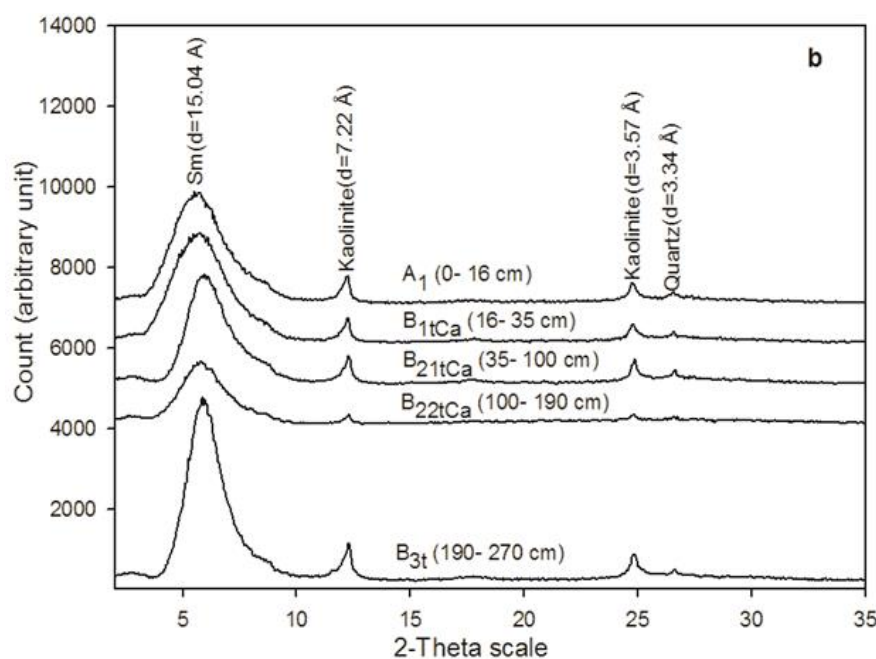

(b)

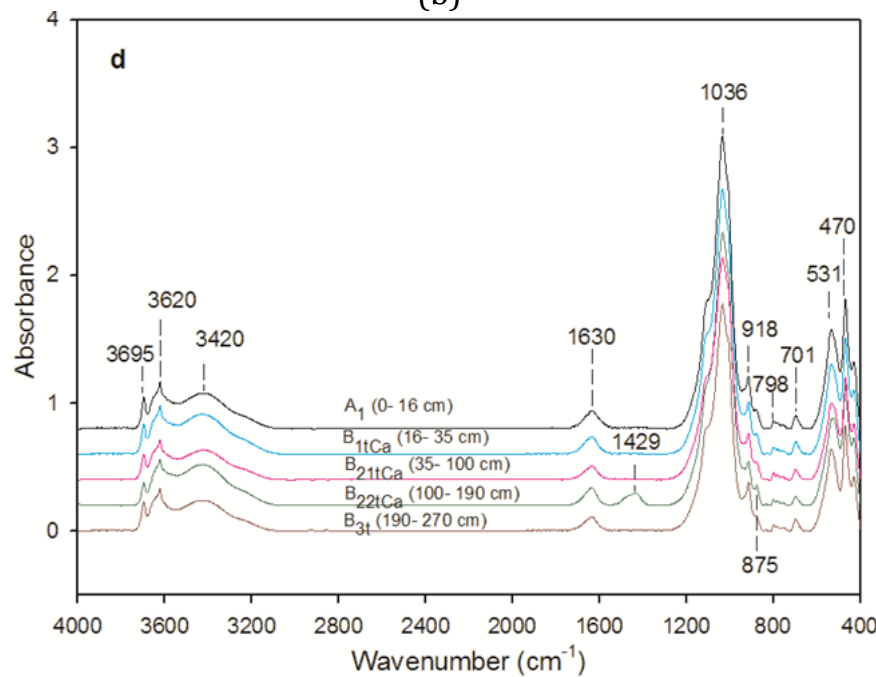

(d)

Figure 2. XRD pattern (a-Velé, b- Bougaye, Sm smectites) and IR spectra (c-Velé, d- Bougaye) of the clay fraction of studied vertisols

The table 3 shows chemical composition of vertisols samples. The major elements were constituted mainly by $\mathrm{SiO}_{2}$ (55.87-83.64\%) followed by $\mathrm{Al}_{2} \mathrm{O}_{3}$ (6.08-20.25\%), $\mathrm{Fe}_{2} \mathrm{O}_{3}$ (2.09-6.39\%) and $\mathrm{K}_{2} \mathrm{O}$ (1.43-2.24). Except $\mathrm{CaO}$ for which proportion in horizons contained calcareous nodules reached to $3.53 \%$, the others major elements were globally less than 1\%. The traces elements were dominated by Ba (518-1202 $\left.\mathrm{mg} \mathrm{kg}^{-1}\right)$, followed by $\mathrm{Zr}$ (334-685 $\mathrm{mg} \mathrm{kg}^{-1}$ ) and Sr (71-190 $\mathrm{mg} \mathrm{kg}^{-1}$ ) (Table 3). 
Table 2. Minerals and their relative abundance in different vertisols samples

\begin{tabular}{|c|c|c|c|c|c|}
\hline Samples & Smectites & Kaolinite & Quartz & Illite & Calcite \\
\hline \multicolumn{6}{|l|}{ Velé profile } \\
\hline $\mathrm{A}_{1}(0-35 \mathrm{~cm})$ & +++ & +++ & ++ & ++ & / \\
\hline $\mathrm{B}_{1 \mathrm{t}}(35-140 \mathrm{~cm})$ & ++++ & +++ & ++ & + & / \\
\hline $\mathrm{B}_{21 \mathrm{tCa}}(140-240 \mathrm{~cm})$ & +++++ & ++++ & +++ & ++ & / \\
\hline $\mathrm{B}_{22 \mathrm{tca}}(240-345 \mathrm{~cm})$ & +++ & ++ & ++ & + & / \\
\hline $\mathrm{B}_{23 \mathrm{tCag}}(345-380 \mathrm{~cm})$ & ++++ & +++ & ++ & ++ & / \\
\hline $\mathrm{B}_{3 \mathrm{G}}(380-405 \mathrm{~cm})$ & ++++ & +++ & ++ & ++ & / \\
\hline \multicolumn{6}{|l|}{ Bougaye profile } \\
\hline $\mathrm{A}_{1}(0-16 \mathrm{~cm})$ & ++++ & +++ & ++ & / & / \\
\hline $\mathrm{B}_{1 \mathrm{tCa}}(16-35 \mathrm{~cm})$ & ++++ & +++ & ++ & / & / \\
\hline $\mathrm{B}_{21 \mathrm{tCa}}(35-100 \mathrm{~cm})$ & ++++ & +++ & ++ & / & / \\
\hline $\mathrm{B}_{22 \mathrm{tCa}}(100-190 \mathrm{~cm})$ & +++ & ++ & ++ & / & ++ \\
\hline$B_{3 t}(190-270 \mathrm{~cm})$ & +++++ & ++++ & ++ & 1 & / \\
\hline
\end{tabular}

++++ very abundant +++ abundant ++ lightly abundant + traces / none

Table 3. Major and selected traces elements in studied vertisols (LOI= loss on ignition)

\begin{tabular}{|c|c|c|c|c|c|c|c|c|c|c|c|}
\hline \multirow{2}{*}{$\begin{array}{l}\text { Profiles } \\
\text { Horizon } \\
\text { Depth }(\mathrm{cm})\end{array}$} & \multicolumn{3}{|c|}{ Velé } & \multirow[b]{2}{*}{$\begin{array}{c}\mathrm{B}_{22 \mathrm{tCa}} \\
(240-345)\end{array}$} & \multirow[b]{2}{*}{$\begin{array}{c}\mathrm{B}_{23 \mathrm{tCag}} \\
(345-380) \\
\end{array}$} & \multirow[b]{2}{*}{$\begin{array}{c}B_{3 G} \\
(380-405)\end{array}$} & \multicolumn{5}{|c|}{ Bougaye } \\
\hline & $\begin{array}{c}A_{1} \\
(0-35)\end{array}$ & $\begin{array}{c}\mathrm{B}_{1 \mathrm{t}} \\
(35-140)\end{array}$ & $\begin{array}{c}\mathrm{B}_{21 \mathrm{tCa}} \\
(140-240)\end{array}$ & & & & $\begin{array}{c}A_{1} \\
(0-16)\end{array}$ & $\begin{array}{l}\mathrm{B}_{1 \mathrm{tCa}} \\
(16-35)\end{array}$ & $\begin{array}{c}\mathrm{B}_{21 \mathrm{tCa}} \\
(35-100)\end{array}$ & $\begin{array}{c}B_{22 t C a} \\
(100-190)\end{array}$ & $\begin{array}{c}\mathrm{B}_{3 \mathrm{t}} \\
(190-270)\end{array}$ \\
\hline $\mathrm{SiO}_{2}(\%)$ & 56.93 & 55.87 & 61.55 & 75.88 & 66.43 & 65.96 & 83.64 & 80.65 & 82.21 & 75.44 & 64.12 \\
\hline $\mathrm{Fe}_{2} \mathrm{O}_{3}(\%)$ & 6.39 & 6.23 & 5.45 & 3.11 & 4.72 & 5.26 & 2.09 & 2.92 & 2.47 & 2.46 & 4.16 \\
\hline $\operatorname{MgO}(\%)$ & 0.79 & 0.93 & 0.93 & 0.41 & 0.66 & 0.42 & 0.38 & 0.56 & 0.55 & 0.81 & 0.5 \\
\hline $\mathrm{CaO}(\%)$ & 0.69 & 0.7 & 0.92 & 0.43 & 1.18 & 0.53 & 0.36 & 0.48 & 0.48 & 3.53 & 0.55 \\
\hline $\mathrm{K}_{2} \mathrm{O}(\%)$ & 1.85 & 1.43 & 1.47 & 1.67 & 1.88 & 2.24 & 2.03 & 1.99 & 1.95 & 2.03 & 2.12 \\
\hline $\mathrm{TiO}_{2}(\%)$ & 1.17 & 1.12 & 0.98 & 0.75 & 0.98 & 0.98 & 0.55 & 0.55 & 0.55 & 0.54 & 1.06 \\
\hline $\mathrm{P}_{2} \mathrm{O}_{5}(\%)$ & 0.10 & 0.05 & 0.03 & 0.02 & 0.02 & 0.10 & 0.02 & 0.01 & 0.02 & 0.02 & 0.06 \\
\hline $\mathrm{MnO}(\%)$ & 0.05 & 0.04 & 0.04 & 0.04 & 0.03 & 0.04 & 0.05 & 0.12 & 0.07 & 0.05 & 0.02 \\
\hline LOI $(\%)$ & 11.90 & 12.90 & 11.50 & 6.70 & 8.70 & 8.20 & 4.50 & 5.30 & 4.60 & 7.90 & 9.20 \\
\hline Total (\%) & 99.95 & 99.96 & 99.97 & 100.00 & 99.97 & 99.97 & 100.01 & 100.00 & 100.01 & 99.99 & 99.96 \\
\hline $\mathrm{Ba}, \mathrm{mg} \mathrm{kg}^{-1}$ & 1202 & 856 & 841 & 589 & 791 & 848 & 533 & 558 & 518 & 592 & 823 \\
\hline $\mathrm{Ni}, \mathrm{mg} \mathrm{kg}^{-1}$ & 50 & 52 & 37 & 22 & 34 & 34 & $<20$ & $<20$ & $<20$ & $<20$ & 36 \\
\hline $\mathrm{Y}, \mathrm{mg} \mathrm{kg}^{-1}$ & 30 & 32 & 22 & 20 & 27 & 34 & 14 & 16 & 16 & 26 & 23 \\
\hline $\mathrm{Nb}, \mathrm{mg} \mathrm{kg}^{-1}$ & 25 & 29 & 21 & 14 & 20 & 18 & 10 & 12 & 10 & 10 & 21 \\
\hline Sc, mg kg-1 & 15 & 16 & 12 & 8 & 11 & 11 & 4 & 5 & 5 & 5 & 13 \\
\hline
\end{tabular}

\section{Suitability to sorghum productivity}

Heavy clay soils poorly drained were usually not submitted to millet, maize, leguminous and cotton cultivation in North Cameroon. Due to the annual flood pattern in rainy season, the studied vertisols were not used for rainy sorghum production. However, they were subjected to dry season sorghum cultivation and sorghum-sorghum system was regularly practiced.

Based on the soil requirement of the dry season sorghum, physicochemical properties of the studied vertisols are suitable. The sorghum has a high capacity to tolerate waterlogging period subsequent to poor drainage and the drought conditions in dry season. Soil water retention capacity is fundamental to dry season sorghum growth. The $\mathrm{pH}$, the phosphorus level, calcium and magnesium reached the required content (Memento de l'Agronome, 1991). The only element less than the required amount is potassium which is highly less than the needed. Globally, for dry season sorghum the fertility status of studied vertisols is appreciable.

According to the data collected from farmers, the mean yield by hectare was about 2 tha $^{-1}$ of sorghum grain on Bougaye vertisols while it was about $1.5 \mathrm{t} \mathrm{ha}^{-1}$ at Velé. It appeared that the nature of the clay fraction was more affecting dry season sorghum productivity than the proportion of clay. It also noted that the vertisols with the high CEC recorded the high sorghum productivity. So, the content of smectites was a key factor promoting the dry season sorghum productivity on vertisols.

Globally, the two studied vertisols are suitable to dry season sorghum cultivation because of their mineralogical and physicochemical characteristics. 


\section{Discussion}

The studied vertisols were globally average deep with surficial desiccation cracks during the dry season in both sites. This feature is common to all clayey soils which alternates dry and wet seasons (Dudal, 1965; Wilding, 2004; Coulombe et al., 1996; Tamfuh et al., 2011; Temga et al., 2015). The micro-relief called gilgai were the most pronounced geomorphology associated to vertisols fields. The dark color characteristic of vertisols was observed in all horizons and regularly throughout the profiles. It was noted that vertisols can have a range of colors depending on the climate, the drainage behavior, the parent material and the topography (Coulombe et al., 1996; Tamfuh et al., 2011; Temga et al., 2015). The constancy of the same color throughout the profile is due to regular homogenization through the vertic movements which mix the entire profile (Tamfuh et al., 2011). Red and yellowish spots observed are the result of poor drainage which promotes temporal hydromorphy. The slickensides are the dominant morphological feature associated to vertisols (Dudal, 1965; Coulombe et al., 1996; Wilding, 2004; Nguetnkam, 2004; Tamfuh et al., 2011; Temga et al., 2015). Globally, the profiles had less horizons differentiation which according Tamfuh et al. (2011) was due to the shrink-swell movements. This fact can be assigned to regular homogenization of the entire profile by pedoturbation process (Coulombe et al., 1996; Nguetnkam, 2004; Tamfuh, 2012; Temga et al., 2015).

On the physical point of view, the studied vertisols were characterized by their heavy texture and their hardness when dried. It was always reported that clay proportion in vertisols was more than $30 \%$ to a depth of $50 \mathrm{~cm}$ or more (Dudal, 1965; Coulombe et al., 1996). The high clay content is responsible for their properties which promotes their suitability for dry season sorghum cultivation (Brabant and Gavaud, 1985; Coulombe et al., 1996; Kenga et al., 2005; Mathieu, 2005; Tamfuh et al., 2011). The both profiles were also marked by the presence of calcareous nodules which is characteristics of flooded and poorly drained environments promoting calcium precipitation. It was reported that carbonates were a common mineral in neutral and alkaline vertisols in which they occurred as calcite (Coulombe et al., 1996).

The different horizons were slightly alkaline to alkaline and not differ significantly along the profiles. The alkaline character of vertisols was sometimes attributed to the calcareous or base-rich parent materials from which they were developed (Nguetnkam, 2004; Moustakas, 2012). Relative higher vertisols pH in the current study compared to those from others part of North Cameroon (Coulombe et al., 1996; Mathieu, 2005; Tamfuh et al., 2011; Temga et al., 2015) could be attributed to the presence of calcareous nodules described. The high cation exchange capacity obtained is more consistent with the predominance of smectites (Table 1) than the high clay content (Table 2). In fact, smectites were recognized to have a high CEC (Caillère et al., 1982). This is one of the factors which classify vertisols as one of the fertile soils from the Northern Cameroon. Topomorphic vertisols are formed on low landscape positions in which poor drainage limit bases leaching promoting bisiallitisation process responsible of smectites synthesis (Blanchart et al., 2000; Nguetnkam et al., 2007; Tamfuh et al., 2011; Temga et al., 2015). Also, weathering process in dry areas with pronounced dry season and low water-flow condition leads to conservation of a part of silica, bases and thus, to neoformation of smectites (Pedro, 1968; Blanchart et al., 2000; Nguetnkam et al., 2007). This class of vertisols was well known in North Cameroon by farmers who called them baleewal because of their dark color. Their high clay content and water retention capacity were appreciated by farmers (Mathieu, 2005). An occurrence of calcite is consistent with the presence of calcareous nodules.

Geochemically, the studied vertisols were dominated by silica $\left(\mathrm{SiO}_{2}\right)$, aluminum $\left(\mathrm{Al}_{2} \mathrm{O}_{3}\right)$ and iron $\left(\mathrm{Fe}_{2} \mathrm{O}_{3}\right)$. Also, alkali and alkalino-earth elements were observed throughout the profiles. According to Tamfuh et al. (2011), the low landscape positions and the strongly contrasted climate is favorable to accumulation of these constituents. This is also consistent with the mineralogy dominated by aluminosilicates (smectites and kaolinite). The high content of $\mathrm{K}_{2} \mathrm{O}$ and $\mathrm{CaO}$ are in agreement respectively with the presence of illites and calcite as well as calcareous nodules. The fact that $\mathrm{Ba}$ and $\mathrm{Sr}$ were the most represented traces elements could be attributed to the low landscape positions and their low mobility (Abbaslou et al., 2014).

The heavy texture of the vertisols coupled to the predominance of smectites on the clay fraction was the features promoting their use for dry season sorghum cultivation. Tamfuh (2012) noted that adaptability of sorghum to vertisols is due to his well-developed and finely branching roots system which could not be damaged by the desiccation cracks. In addition, his very small leaves limit evapotranspiration in dry season. An important factor contributing to vertisols productivity in semi-arid zones is their high water holding capacity. For instance, it is well known that the Muskwari (dry season sorghum) production depends on the soil water reserve accumulated during the rainy season which is conditioned by the poorly drainage of the 
soil subsequent to his high content in 2:1 clay minerals (Tabo et al., 2002; Mathieu et al., 2002; Mathieu, 2005; Tamfuh et al., 2011). So, the water retention capacity of the soil which is associated to the content in swelling clays is fundamental to obtaining high yield. This is why vertisols from Bougaye had relative higher sorghum yield than those from Velé. However, the main problems associated to cropping these soils are the difficulty inherent to their management because of their swelling/shrinking behavior. In order to sustain soil productivity, crop has to be rotated in order to improve their hydro physical status.

\section{Conclusion}

This study was focused on the description of vertisols features used for sorghum production in North Cameroon. Studied vertisols were developed on alluvial materials and were globally average thin showing desiccation cracks at surface. The structure was globally angular blocky with calcareous nodules towards the bottom of the profiles. They were clayey, alkaline and displayed a high CEC. Smectites were the main minerals; they were associated to kaolinite and a lesser amount of quartz. Calcite was also observed in some horizons mainly at Bougaye profile. $\mathrm{Si}_{2}, \mathrm{Al}_{2} \mathrm{O}_{3}$, and $\mathrm{Fe}_{2} \mathrm{O}_{3}$ were the dominant oxides. Globally, based on their features, studied vertisols were suitable to dry season sorghum cultivation. However, the yield of this crop seemed to be more dependent on smectites content than the textural class (clay proportion) of the vertisols.

\section{References}

Abbaslou, H., Martin, F., Abtahi, A., Moore, F., 2014. Traces elements concentrations and background values in the arid soils of Hormozgan province of southern Iran. Archives of Agronomy and Soil Science 60(8): 1125-1143.

Adjia, H.Z., Villiéras, F., Kamga, R., Thomas, F., 2013. Mineralogy and physic-chemical properties of alluvial clays from far-north Cameroon: A tool for an environmental problem. International Journal of Water Resources and Environmental Engineering 5(1): 54-66.

Ambassa-Kiki, R., Aboubakar, Y., Boulama, T., 1996. Zero-tillage for rice production on Cameroonian vertisols. Soil and Tillage Research 39(1-2): 75-84.

Ben Hassine, H., 2006. Mineralogical nature and nutritional role of cereal soil clays in subhumid and semi-arid zones (Tunisia). Comptes Rendus Geoscience 338(5): 329-340.

Blanchart, E., Achouak, W., Albrecht, A., Barakat, M., Bellier, G., Cabidoche, Y.M., Hartmann, C., Heulin, T., Lané-Larrouy, C., Laurent, J.Y., Mathieu, M., Thomas, F., Villemin, G., Watteau, F., 2000. Déterminants biologiques de l'agrégation dans les vertisols des petites Antilles. Conséquences sur l'érodibilité. Etude et Gestion des Sols 7(4): 309- 328. [in French]

Brabant, P., Gavaud, M., 1985. Soils and land resources of North Cameroon (North and Far North Provinces). Paris, ORSTOM-MESRES-IRA. [in French]

Caillère, S., Henin, S., Rautureau, M., 1982. Minéralogie des argiles : Classification et nomenclature (Tome 2). Masson (éd). 189p. [in French]

Coulombe, C.E., Wilding, L.P., Dixon, J.B., 1996. Overviews of vertisols: Characteristics and impacts on society. Advances in Agronomy 57: 289-375.

Dudal, R., 1965. Dark clay soils of tropical and subtropical regions. Food and Agriculture Organization of the United Nations (FA0), Agricultural Development. Paper No 83, Rome, Italy, 172 p.

Dudal, R., Eswaran, H., 1988. Distribution, properties and classification of vertisols. In: Vertisols: their distribution, properties, classification and management. Wilding, L.P., Puentes, R. (Eds.). Texas A\&M University, Printing Centre, College Station, Texas, USA. pp. 1-22.

Farmer, V.C., 1979. Infrared spectroscopy. In: Data handbook for clay materials and other non-metallic minerals. Van Olphen, H., Fripiat, J.J. (Eds.). Perganon Press, Oxford, UK. pp. 285-330.

Kenga, R., Njoya A., M'biandoun, M., 2005. Analysis of constraints to agricultural production in the sudano savanna zone of Cameroon and implication for research priority setting. Tropicultura 23(2): 91-99.

Kovda, I.V., Wilding L.P., 2004. Vertisols: problems of classification, evolution and spatial self-organization. Eurasian Soil Science 37(12): 1341-1351.

Mathieu, B., 2005. Une démarche agronomique pour accompagner le changement technique : cas de l'emploi des herbicides dans les systèmes de culture à sorgho repiqué au Nord-Cameroun. Thèse de Doctorat; Institut National Agronomique Paris Grignon, 234p. [in French]

Mathieu, B., Fotsing, E., Gautier, D., 2002. L'extension récente du muskuwaari au Nord-Cameroun : Dynamique endogène et nouveaux besoins de recherche. In: Savanes africaines : des espaces en mutation, des acteurs face à de nouveaux défis. Jamin J.Y., Seiny Boukar, L., Floret, C. (Eds.). Actes du colloque, mai 2002, Garoua, Cameroun. Prasac, N'Djamena, Tchad - Cirad, Montpellier, France. [in French]

Mémento de l’Agronome. 1991. République Française, Ministère de la Coopération et du Développement 1635 p. [in French]

Moustakas, N.K., 2012. A study of vertisol genesis in North Eastern Greece. Catena 92: 208-215.

Munsell Soil Color Chart, 2014. Available at [Access date: 13.02.2018]: https://munsell.com/color-products/colorcommunications-products/environmental-color-communication/munsell-soil-color-charts/ 
Nguetnkam, J.P., 2004. Les argiles des vertisols et des sols fersiallitiques de l'Extrême Nord du Cameroun: genèse, propriétés cristallochimiques et texturales, typologie et application à la décoloration des huiles végétales. Thèse Doct., Univ. Yaoundé I, Cameroon. 216p. [in French]

Nguetnkam, J.P., Kamga, R., Villiéras, F., Ekodeck, G.E., Yvon, J., 2007. Altération du granite en zones tropicales. Exemple de deux séquences étudiées au Cameroun (Afrique centrale). Etude et Gestion des Sols 14(1): 31-41. [in French]

Nzeukou Nzeugang, A., Medjo, E.R., Fagel, N., Kamgang, K.B., Njoya, A., Balo M.A., Mache, J.R., Melo, C.U., 2013. Characterization of clay deposits of Nanga-Eboko (Central Cameroon): suitability for the production of building materials. Clay Minerals 48(4): 655-662.

Pedro, G., 1968. Distribution des principaux types d'altération chimique a la surface du globe. Revue de Géographie Physique et Géologie Dynamique 10(5): 457-470. [in French]

Rahim, I.S., Wahba, M.M., Amal, M.A., 2015. Micromorphological characteristics of vertisols in Egypt. International Journal of Research in Management 5(6): 1-7.

Raunet, M., 2003. Quelques clés morpho-pédologiques pour le Nord Cameroun à l'usage des agronomes. CIRAD, Montpellier, 24 p. [in French]

Tabo, R., Olabanji, O.G., Ajayi, O., Flower, D.J., 2002. Effect of plant population density on the growth and yield of sorghum varieties grown on vertisols. African Crop Science Journal 10(1): 31-38.

Tamfuh, P.A., 2012. Petrological, physico-chemical and mechanical study of the Benue watershed vertisols (North Cameroon): spatial analysis and agricultural potential evaluation. Ph.D Thesis, University of Yaoundé 1; Yaoundé, Cameroon. 172p.

Tamfuh, P.A., Woumfo, E.D., Bitom, D., Njopwouo, D., 2011. Petrological, physico-chemical and mechanical characterization of the topomorphic vertisols from the Sudano-sahelian region of North Cameroon. The Open Geology Journal 5: 33-55.

Temga, J.P., Nguetnkam, J.P., Balo, M.A., Basga, S.D., Bitom, D.L., 2015. Morphological, physico chemical, mineralogical and geochemical properties of vertisols used in bricks production in the Logone Valley (Cameroon, Central Africa). International Research Journal of Geology and Mining 5(2): 20-30.

Walkley, A., Black, C.A., 1934. An examination of Digestion method for determining soil organic matter and proposed modification of the chromic acid titration method. Soil Science 37(1): 29-38.

Wilding, L.P., 2004. Advancement in the knowledge base of vertisols genesis, classification, distribution and management. Revista Científica Agropecuaria 8(1): 45-54.

WRB, 2014. World reference base for soil resources 2014. International soil classification system for naming soils and creating legends for soil maps. World Soil Resources Reports 106. Food and Agriculture Organization of the United Nations. Rome, Italy. Available at [access date: 13.02.2018]: http://www.fao.org/3/a-i3794e.pdf 